\title{
Kinesiotherapy for quality of life, pain and muscle strength of rheumatoid arthritis and systemic lupus erythematosus patient. Case report*
}

\author{
Intervenção cinesioterapêutica na qualidade de vida, dor e força muscular de paciente portador \\ de artrite reumatoide e lúpus eritematoso sistêmico. Relato de caso
}

Rafaela Simon Myra1', Mariângela DeMarco², Caroline Zanin³, Lia Mara Wibelinger ${ }^{4}$

${ }^{*}$ Received from University of Passo Fundo, Passo Fundo, RS, Brazil.

DOI 10.5935/1806-0013.20150029

\section{ABSTRACT}

BACKGROUND AND OBJECTIVES: Rheumatoid arthritis is an inflammatory, chronic and progressive disease. It impairs joint synovial membranes and may induce bone and cartilage destruction. Many diseases may follow rheumatoid arthritis, including systemic lupus erythematosus, an inflammatory, chronic autoimmune disease with multisystemic manifestations, with periods of remission and exacerbation. This study aimed at reporting kinesiotherapy intervention for quality of life, pain and muscle strength of a patient with rheumatoid arthritis and systemic lupus erythematosus.

CASE REPORT: Female patient, 49 years old, diagnosed 15 years ago with rheumatoid arthritis and systemic lupus erythematosus. Patient complained of pain on hands, feet and lumbar spine, with irradiation to lower limb and morning stiffness. Tool to measure muscle function was Biodex System3 Pro isokinetic dynamometer in the speeds of 120 and $240^{\circ}$ during knee flexion and extension movements, in addition to the Short-Form Health Survey questionnaire and pain evaluation by the visual analog scale.

CONCLUSION: The study has shown that kinesiotherapybased physiotherapy is effective to relieve pain and improve muscle strength and quality of life of patient with systemic lupus erythematosus and rheumatoid arthritis.

Keywords: Muscle strength, Pain, Physiotherapy, Quality of life, Rheumatoid arthritis, Systemic lupus erythematosus.

1. University of Passo Fundo, School of Physiotherapy, Scholarship Grantee, Pibic/CNPQ, Carazinho, RS, Brazil.

2. University of Passo Fundo, School of Physiotherapy, Scholarship Grantee, Pibic/CNPQ, Sarandi, RS, Brazil.

3. University of Passo Fundo, School of Physiotherapy, Săo Jorge, RS, Brazil.

4. University of Passo Fundo, School of Physiotherapy, Passo Fundo, RS, Brazil.

Submitted in January 20, 2015.

Accepted for publication in April 29, 2015

Conflict of interests: none - Sponsoring sources: none.

Correspondence to:

Rafaela Simon Myra

BR 285, Bairro São José

99052-900Passo Fundo, RS, Brasil.

E-mail: rafaelasimonmyra@gmail.com

(C) Sociedade Brasileira para o Estudo da Dor

\section{RESUMO}

JUSTIFICATIVA E OBJETIVOS: A artrite reumatoide é uma doença inflamatória, crônica e progressiva. Compromete a membrana sinovial das articulaçóes, podendo causar destruição óssea e cartilaginosa. Muitas doenças podem cursar com a artrite reumatoide, uma delas é o lúpus eritematoso sistêmico, uma doença inflamatória crônica, autoimune, com manifestaçóes multissistêmicas, apresentando períodos de remissão e exacerbação. $\mathrm{O}$ objetivo deste estudo foi relatar a intervenção cinesioterapêutica na qualidade de vida, dor e força muscular de um indivíduo portador de artrite reumatoide e lúpus eritematoso sistêmico.

RELATO DO CASO: Paciente do gênero feminino, 49 anos, diagnosticada há 15 anos como portadora de artrite reumatoide e lúpus eritematoso sistêmico. Apresentava queixa de dor nas mãos, nos pés e coluna lombar com irradiação para o membro inferior; rigidez matinal. $\mathrm{O}$ instrumento utilizado para medir a função muscular foi o dinamômetro isocinético Biodex System3 Pro nas velocidades de 120 e $240^{\circ}$ nos movimentos de flexão e extensão de joelho, além da aplicação do questionário Short-Form Health Survey e avaliação da dor por meio da escala analógica visual.

CONCLUSÁO: Este estudo mostrou que a fisioterapia baseada na cinesioterapia é eficaz para a diminuição da dor, melhorar a força muscular e gera progresso na qualidade de vida em um paciente portador de lúpus eritematoso sistêmico e artrite reumatoide.

Descritores: Artrite reumatoide, Dor, Fisioterapia, Força muscular, Lúpus eritematoso sistêmico, Qualidade de vida.

\section{INTRODUCTION}

Pain is multidimensional and classified as unpleasant sensory and emotional experience ${ }^{1}$. Muscle and joint pains affect individuals' functionality, changing their daily routine ${ }^{2}$. Rheumatoid arthritis (RA) and systemic lupus erythematosus (SLE) patients often indicate pain as major symptom of the disease ${ }^{3,4}$.

RA is a chronic, autoimmune, inflammatory disease of unknown etiology which affects joint synovial membranes causing bone and cartilage destruction ${ }^{5}$. Body joints are symmetrically affected, with further involvement of hands 
and feet ${ }^{6}$. It is more prevalent in females and in general develops between the fourth and fifth decades of life ${ }^{7}$. Because of its chronic and destructive character, it leads to functional limitation and poorer quality of life $(\mathrm{QL})^{8}$.

Other diseases may follow RA, among them SLE ${ }^{8-10}$. SLE is a chronic, inflammatory autoimmune disease. It has multisystemic manifestations and unknown etiology, with remission and exacerbation periods ${ }^{11}$. There is skin, visceral ${ }^{12}$ and joint ${ }^{13}$ involvement, in addition to myalgia, osteoporosis ${ }^{14}$ and pain ${ }^{15}$, among others.

Physiotherapy is very important for painful patients. Several mechanisms may be influenced by physiotherapeutic techniques, thus contributing for patients' management ${ }^{16}$.

So, this study aimed at evaluating pain, muscle strength and QL before and after physiotherapeutic treatment in RA and SLE patients.

\section{CASE REPORT}

Female patient, 49 years old, diagnosed 15 years ago with RA and SLE. Patient complained of pain in hands, feet and lumbar spine with irradiation to lower limb (LL) and morning stiffness. The following drugs were administered during treatment: levothyroxin $(88 \mathrm{mg})$ used for hormonal replacement therapy in patients with hypothyroidism of any etiology; prednisone $(5 \mathrm{mg})$, used to treat endocrine and musculoskeletal diseases, collagen disorders and dermatologic diseases; enalapril $(10 \mathrm{mg})$, used for hypertension and heart failure; and folic acid supplement (vitamin B9), which is an anti-anemia agent.

Evaluation has collected data such as: gender, age, medical diagnosis and associated diseases. Tools were visual analog scale (VAS) and QL questionnaire - Medical Outcomes Study 36 - Item Short-Form Health Survey (SD-36, in addition to isokinetic evaluation.

Muscle function parameters were evaluated with isokinetic dynamometer Biodex System3 Pro (Biodex Medical System, Shirley, NY, USA), electromechanical equipment to quantitatively evaluate physical parameters of muscle function ${ }^{17}$. Pain was evaluated with VAS which, according to the American College of Rheumatology, checks pain levels in individuals with rheumatic diseases ${ }^{18}$.

QL was evaluated with SF-36, applied after previous explanation and answering of questions. SF-36 is made up of 36 items, gathered in physical and mental components ${ }^{19}$.

Patient was submitted to 15 physiotherapy sessions, during three months, twice a week and lasting $50 \mathrm{~min}$. Protocol was based on kinesiotherapy and consisted of: initial and final blood pressure; global active-passive stretching and with Swiss ball; muscle strengthening of arms flexors, extensors and abductors, elbow flexors and extensors (blue elastic band $3 \times 10$ ); strengthening of ankle plantiflexors and dorsiflexors and ankle inverters and everters (digiflex progressively increasing load); weight unload; balance and proprioception exercises (airex); wrist, ankle and toes joint mobilization; massage therapy on dorsal region and cervical pompage. Post-intervention evaluation was carried out after the last physiotherapy session.

Table 1 shows muscle torque peak of knee flexors pre and post physiotherapy intervention by means of isokinetic dynamometer.

Table 1. Knee flexors muscle torque peak

\begin{tabular}{lcccc}
\hline & \multicolumn{2}{c}{ Pre } & \multicolumn{2}{c}{ Post } \\
Speeds & Left & Right & Left & Right \\
\hline $120^{\circ}$ & 7.8 & 8.1 & 21.4 & 24.4 \\
$240^{\circ}$ & 10.0 & 8.5 & 21.9 & 30.9 \\
\hline
\end{tabular}

For knee flexion movement, there has been right (RLL) and left (LLL) lower limb torque peak improvement in both speeds. At $120^{\circ}$ there has been $202.5 \%$ strength improvement in RLL, and in LLL of $175 \%$. At $240^{\circ}$ there has been $118.8 \%$ improvement for LLL and of $265.7 \%$ for RLL. Table 2 shows knee extensors muscle torque peak pre and post intervention.

Table 2. Knee extensors muscle torque peak

\begin{tabular}{lcccc}
\hline & \multicolumn{2}{c}{ Pre } & \multicolumn{2}{c}{ Post } \\
Speeds & Left & Right & Left & Right \\
\hline $120^{\circ}$ & 26.7 & 22.3 & 56.8 & 55.9 \\
$240^{\circ}$ & 24.6 & 20.6 & 38.9 & 43.8 \\
\hline
\end{tabular}

Results show increased torque peak in both speeds for RLL and LLL. At $120^{\circ}$ speed there has been $150.1 \%$ improvement for RLL and at $240^{\circ}$ it was $112.7 \%$. For LLL there has been $112 \%$ improvement at $120^{\circ}$ and of $57.8 \%$ at $240^{\circ}$. Table 3 shows QL results, obtained with SF-36. First four domains address physical health and four last domains address mental health. Scores vary from zero to 100 , where zero is the worst and 100 the best score.

Table 3. Quality of life

\begin{tabular}{lcc}
\hline Domains & Pre & Post \\
\hline Functional capacity & 25 & 40 \\
Limitation by physical aspects & 0 & 25 \\
Pain & 20 & 50 \\
General health status & 27 & 17 \\
Vitality & 50 & 35 \\
Social aspects & 25 & 15 \\
Limitation by emotional aspects & 0 & 4 \\
Mental health & 48 & 56 \\
\hline
\end{tabular}

There has been general QL improvement and maintenance after physiotherapy. Percentage variation shows major $150 \%$ increment on pain domain, followed by social aspects $(66.67 \%)$ and functional capacity $(60 \%)$.

When evaluating pre-physiotherapy pain by VAS, patient has reported score 10 , and after intervention it was considerably decreased (60\%), reaching score 4 . 


\section{DISCUSSION}

Muscle pain during static contraction decreases painful muscle activity and attenuates synergic muscles ativity ${ }^{20}$. Abnormal motor behavior is evidenced by changes in performing some activity, because the body compensates other muscles to be able to perform certain movements, thus contributing to worsen pain ${ }^{21}$. It was observed that both for extension and flexion movements at $120 \%$ s there has been further improvement as compared to $240 \%$ s, showing that as speed increases, torque peak decreases.

In chronic pain, symptoms persist beyond the physiological recovery period of the injured tissue, worsening $\mathrm{QL}$, wellbeing, physical and cognitive capacity. Chronic pain management, differently from acute pain therapies (rest and drugs), is made up by physical exercises and multidisciplinary management ${ }^{22}$. Intervention with physiotherapy is critical for SLE patients, restoring physical and mental wellbeing and improving QL, because when participating in a regular physiotherapy program, patient has improved her pain with consequent improvement of muscle strength and fatigue parameters, in addition to improving QL in most domains.

Meireles et al. ${ }^{23}$ have evaluated torque peak, work and potency of 50 individuals with RA and 50 healthy ones, with speeds of $60 \% / \mathrm{s}, 80 \% \mathrm{~s}$ and $300 \%$ s. They have observed that RA patients had lower values as compared to healthy participants in all variables. This information is in line with results of this case report, where participant had low torque peak values as observed by isokinetic evaluation scores.

As in SLE, a predominant RA symptom is pain ${ }^{24,25}$, in addition to distal joints edema, stiffness and weakness ${ }^{26}$. So RA management should be multidisciplinary, including pharmacological, psychological and physiotherapeutic approaches, primarily based on kinesiotherapy ${ }^{24}$, as proposed for our case, providing a tailored protocol for patient's needs.

In addition to improving pain and QL, Pereira et al. ${ }^{26}$ have also observed that physiotherapeutic management of RA should be made of passive exercises in the early phases and of active, isometric and/or isotonic exercises. These exercise programs aim at assuring maintenance, recovery or improvement of joint movement amplitude, strength, muscle stretching and aerobic capacity improvement.

\section{CONCLUSION}

Physiotherapy based on kinesiotherapy is effective to improve pain, muscle strength and QL in SLE and RA pa- tients. However, one has to be aware that each person has different symptoms and limitations so physical activity intensity, frequency and duration should be tailored.

\section{REFERENCES}

1. Merskey H, Bogduk N, International Association for the Study of Pain. Classification of chronic pain: descriptions of chronic pain syndromes and definitions of pain terms. 2a ed. Seatle: Iasp Press; 2002. 240p.

2. Graven-Nielsen T, Arendt-Nielsen L. Impact of clinical and experimental pain on muscle strength and activity. Curr Rheumatol Rep. 2008;10(6):475-81.

3. Heiberg T, Kvien TK. Preferences for improved health examined in 1,024 patients with rheumatoid arthritis: pain has highest priority. Arthritis Rheum. 2002;47(4):391-7.

4. Sociedade Brasileira de Reumatologia. Cartilha Lúpus. São Paulo. Disponível em (http://www.nlm.nih.gov/bsd/uniform_requirements.html). 2011;1-21

5. Lee DM, Weinblatt ME. Rheumatoid arthritis. Lancet. 2001;15;358(9285):903-11.

6. Verstappen SM, van Albada-Kuipers GA, Bijlsma JW, Blaauw AA, Schenk Y, Haanen $\mathrm{HC}$, et al. A good response to early DMARD treatment of patients with rheumatoid arthritis in the first year predicts remission during follow up. Ann Rheum Dis. 2005;64(1):38-43.

7. Silman AJ, Pearson JE. Epidemiology and genetics of rheumatoid arthritis. Arthritis Res. 2002;4(Suppl 3):S265-72.

8. Woolf AD. How to assess musculoskeletal conditions. History and physical examination. Best Pract Res Clin Rheumatol. 2003;17(3):381-402.

9. Mease PJ. Inflammatory musculoskeletal disease: identification and assessment. J Rheumatol. 2011;38(3):557-61.

10. Scott DL, Wolfe F, Huizinga TW. Rheumatoid arthritis. Lancet. 2010;376(9746):1094108 .

11. Pezzole ER, Oselame GB. Fatores de risco para o lúpus eritematoso sistêmico: revisão da literatura. Rev Uniandrade. 2014;15(1):65-77.

12. dos Reis MG, da Costa IP. [Health-related quality of life in patients with systemic lúpus erythematosus in Midwest Brasil]. Bras Reumatol. 2010;50(4):408-22. English, Portuguese.

13. Sato EI, Bonfá ED, Costallat LT, Silva NA, Brenol JC, Santiago MB, et al. Lúpus eritematoso sistêmico: acometimento cutâneo/articular. Rev Assoc Med Bras. 2006;52(6):375-8.

14. Gordon C, Li CK, Isenberg DA. Systemic lupus erythematosus. Medicine 2010;38(2):73-80

15. Póvoa TI. Lúpus eritematoso sistêmico, exercício físico e qualidade de vida. Artigo de Revisão EFDeports.com, Rev Digital [online]. Disponível em: http://www.efdeportes. com/efd144/lupus-eritematoso-sistemico-exercicio-fisico.htm. 2010/15(144).

16. Gosling AP. Mecanismos de açấo e efeitos da fisioterapia no tratamento da dor. Rev Dor. 2013;13(1):65-70.

17. Drouin JM, Valovich-McLeod TC, Shultz SJ, Gansneder BM, Perrin DH. Reliability and validity of the Biodex system 3 pro isokinetic dynamometer velocity, torque and position measurements. Eur J Appl Physiol. 2004;91(1):22-9.

18. Torres TM, Ciconelli RM. Instrumentos de avaliação em espondilite anquilosante Rev Bras Reumatol. 2006;46(Suppl 1):52-9.

19. Ferreira LR, Pestana PR, Oliveira J, Mesquita-Ferrari RA. Efeitos da reabilitação aquática na sintomatologia e qualidade de vida de portadoras de artrite reumatoide. Rev Fisioter Pesq. 2008;15(2):136-41.

20. Falla D, Farina D, Dahl MK, Graven-Nielsen T. Muscle pain induces task-dependent changes in cervical agonist/antagonist activity. J Appl Physiol. 2007;102(2):601-9.

21. Ervilha UF, Arendt-Nielsen L, Duarte M, Graven-Nielsen T. Effect of load level and muscle pain intensity on the motor control of elbow-flexion movements. Eur J Appl Physiol. 2004;92(1-2):168-75.

22. Souza JB. Poderia a atividade física induzir analgesia em pacientes com dor crônica? Rev Bras Med Esporte. 2009;15(2):145-50.

23. Meireles SM, Oliveira LM, Andrade MS, Silva AC, Natour J. Isokinetic evaluation of the knee in patients with rheumatoid arthritis. Joint Bone Spine. 2002;69(6):566-73.

24. Walsh DA, McWilliams DF. Mechanisms, impact and management of pain in rheumatoid arthritis. Nat Rev Rheumatol. 2014;10(10):581-92.

25. Lee DM, Weinblatt ME. Rheumatoid arthritis. Lancet. 2001;358(9285):903-11.

26. Pereira IA, Mota LM, Cruz BA, Brenol CV, Fronza LS, Bertolo MB, et al. [2012 Brazilian Society of Rheumatology Consensus on the management of comorbidities in patients with rheumatoid arthritis]. Rev Bras Reumatol. 2012;52(2):474-95. English, Portuguese. Erratum in: Rev Bras Reumatol. 2012;52(5):815. 